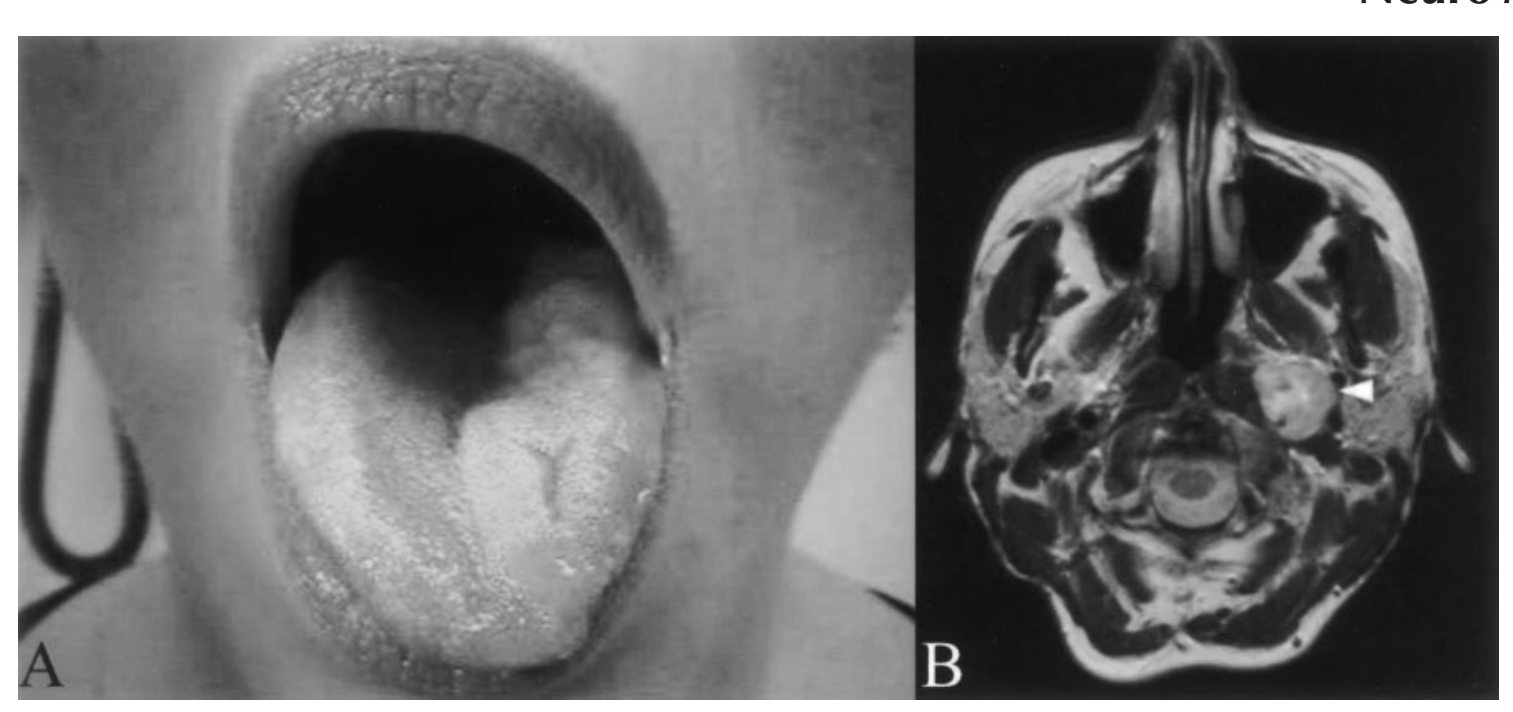

Figure. (A) Photograph depicting atrophy and furrowing of the leftward-deviating tongue. (B) Axial T2-weighted image of a $2.2 \times 2.3-\mathrm{cm}$ left hypoglossal nerve schwannoma (arrow).

\section{vIDE0 Extracranial hypoglossal schwannoma}

Annemarei Ranta, MD; W. Christopher Winter, $M D$; and Ivan S. Login, $M D$

A 55-year-old woman seen for chronic daily headaches had a normal examination except that her left tongue showed atrophy

From the Department of Neurology, University of Virginia Health Sciences Center, Charlottesville.

Received November 7, 2002. Accepted in final form January 10, 2003.

Address correspondence and reprint requests to Dr. I.S. Login, Department of Neurology, University of Virginia, P.O. Box 800394, Charlottesville, VA 22908; e-mail: isl@hscmail.mcc.virginia.edu with fasciculations and protruded leftward. She and her dentist were unaware of these changes, and she denied speech or swallowing difficulties. MRI demonstrated a solitary enhancing extracranial lesion that extended from the left hypoglossal canal to the poststyloid parapharyngeal space abutting the cranial base without intracranial extension. The differential diagnosis included schwannoma, paraganglioma, lymphoma, or metastatic disease. The excised tumor was a schwannoma (figure; video). Isolated extracranial hypoglossal schwannoma without neurofibromatosis is uncommon.

Video Legend. Tongue fasciculations ("bag of worms"), atrophy, and deviation secondary to a left hypoglossal nerve schwannoma. 


\title{
Neurology
}

\author{
Extracranial hypoglossal schwannoma \\ Annemarei Ranta, W. Christopher Winter and Ivan S. Login \\ Neurology 2003;60;E11 \\ DOI 10.1212/01.WNL.0000060184.63911.B0
}

This information is current as of June 24, 2003

Updated Information \&

Services

Supplementary Material

Subspecialty Collections

Permissions \& Licensing

Reprints including high resolution figures, can be found at:

http://n.neurology.org/content/60/12/E11.full

Supplementary material can be found at:

http://n.neurology.org/content/suppl/2003/06/24/60.12.E11.DC1

This article, along with others on similar topics, appears in the following collection(s):

All Imaging

http://n.neurology.org/cgi/collection/all_imaging

All Oncology

http://n.neurology.org/cgi/collection/all_oncology

Cranial neuropathy

http://n.neurology.org/cgi/collection/cranial_neuropathy

MRI

http://n.neurology.org/cgi/collection/mri

Nerve tumor

http://n.neurology.org/cgi/collection/nerve_tumor

Information about reproducing this article in parts (figures,tables) or in its entirety can be found online at:

http://www.neurology.org/about/about_the_journal\#permissions

Information about ordering reprints can be found online:

http://n.neurology.org/subscribers/advertise

Neurology ${ }^{\circledR}$ is the official journal of the American Academy of Neurology. Published continuously since 1951, it is now a weekly with 48 issues per year. Copyright. All rights reserved. Print ISSN: 0028-3878. Online ISSN: 1526-632X.

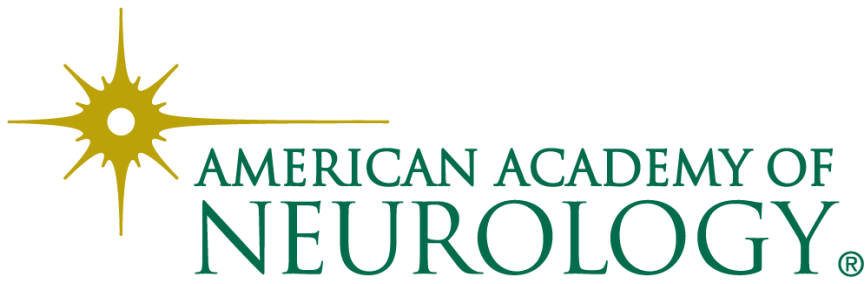

